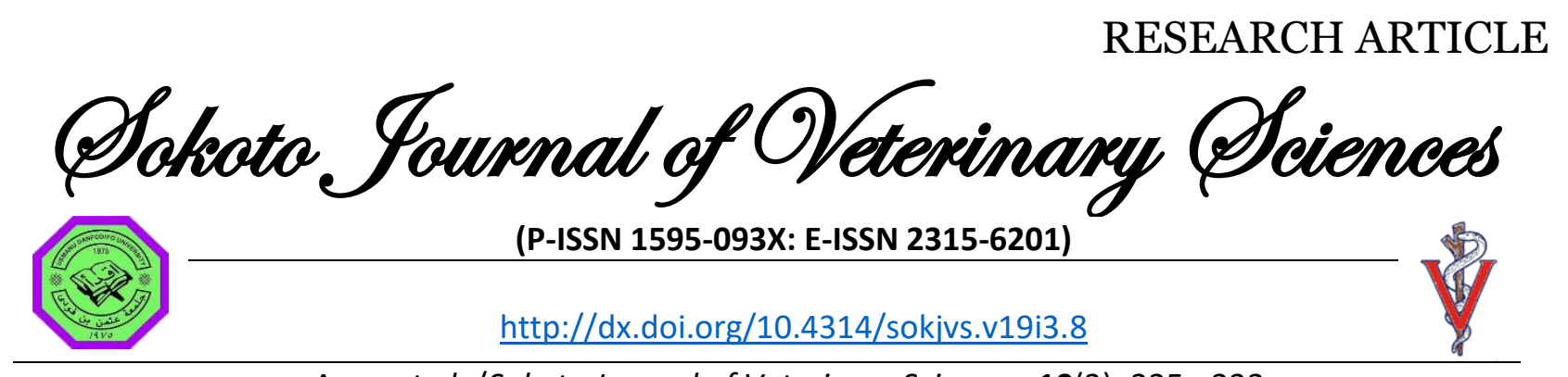

Agyo et al. /Sokoto Journal of Veterinary Sciences, 19(3): 225 - 232.

\title{
Lead and coliform contaminants in groundwater sources in peri-urban areas of Makurdi, Nigeria
}

\author{
RA Agyo*, RA Ofukwu, CA Agada \& AEJ Okoh \\ Department of Veterinary Public Health and Preventive Medicine, Federal University of Agriculture, Makurdi, \\ Nigeria
}

*Correspondence: Tel.: +2348034854720; E-mail: ruthagyo@gmail.com

\begin{abstract}
Copyright: (c) 2021
Agyo et al. This is an open-access article published under the terms of the Creative Commons Attribution License which permits unrestricted use, distribution, and reproduction in any medium, provided the original author and source are credited.
\end{abstract}

Publication History: Received: 07-04-2021

Revised: 22-06-2021

Accepted: 26-06-2021

\begin{abstract}
Benue State has one of the most populated state capitals in North-central Nigeria, suffering from acute water shortage despite River Benue that runs through the town. The combined effect of inadequate potable water supply and the polluted nature of the River has pushed the populace, especially peri-urban residents, to resort to water from wells and boreholes. This study investigates the possible contamination by lead, and some waterborne pathogenic bacterial burden of water from wells and boreholes. Four peri-urban areas of Makurdi, Nigeria, were selected for the study. A total of 768 samples were randomly collected, 192 from each location. The presence of lead was quantified using Atomic Absorption Spectrophotometer, while the bacteriological assessment was done using Multiple Tube Fermentation Techniques and biochemical tests. The mean value for lead at the different sampling sites ranged from 0.030 to $0.079 \mathrm{mg} / \mathrm{L}$. The mean value of lead in all the wells and locations was significantly $(P<0.05)$ higher than the WHO recommended values of $0.01 \mathrm{mg} / \mathrm{L}$ for lead. Five species of pathogenic bacteria were isolated and identified, namely $E$. coli, Salmonella subsp 3B, Enterobacter pagglomeran complex, Klebsiella pneumoniae and Citrobacter freundii. The mean value for $E$. coli at the different well types ranged from 0.000 to 0.401 CFUX10 and were significantly $(P<0.05)$ different. Water from wells in Makurdi had high lead concentration as well as enteric pathogenic bacteria that render it not fit for human consumption. It is recommended that regulatory agencies should protect wells through the development of relevant guidelines to address the risk of water contamination.
\end{abstract}

Keywords: Contamination, Enteric bacteria, Groundwater, Lead

\section{Introduction}

There is a famous saying that 'Water is life' Water is precious and necessary for the sustainable economic development of an area. Potable water plays an essential role in promoting human health and wellbeing (UNICEF, 2017; WHO, 2017). Domestic water supplies are among the fundamental requirements for human life. Without water, life cannot be sustained beyond few days, and lack of access to adequate water supply leads to the spread of diseases (Mintz et al., 2001). Benue State is 
predominantly one of the rural states in Nigeria, with over $70 \%$ of the population living in rural areas. This segment of the population is faced with problems of acute water supply shortages. Traditional water supply sources such as streams, rivers and lakes have come under intense stress due to deforestation activities such as land clearance and bush burning. Some of these sources have disappeared entirely or are heavily polluted. Women and children who are the major drawers of water suffer untold hardship, especially in the dry season, scavenging for water for household use. Families are exposed to all types of health problems that are water-related (Ocheri et al., 2012). The scarcity of potable water has made communities to find alternative sources of water; wells are common groundwater sources readily explored to meet community water requirements or make up the short fall (Adekunle, 2008). This is the situation in Makurdi. Although Makurdi is situated on the bank of the River Benue, households here are forced to use unreliable sources of water like shallow wells and the River Benue itself, with wells being the major source of water for household uses. This is insufficient to supply adequate water to the rapid population increase. Thousands of people, especially the poor, lack sufficient access to potable drinking water. Those most susceptible to water borne illnesses are children, the elderly, pregnant women and immune-compromised individuals, making water-borne diseases one of the five leading causes of death among children under age five (Gerba et al., 1996). Estimates from the World Health Organization (WHO) indicates that about 884 million people in the world still do not get their drinking water from approved sources and $89 \%$ of these people live in developing countries (WHO, 2017). Many serious diseases, such as cholera, typhoid fever, hepatitis, are caused by drinking water that contains pathogenic organisms and water containing a large amounts of agricultural chemicals, e.g., pesticides (Won, 2012; Ocheri et al., 2014; WHO, 2017; UNICEF, 2018). Natural processes and anthropogenic activities of man, such as farming, can contaminate groundwater (Won, 2012). The effects of lead overdose include severe kidney and brain damage (Jaishankar et al., 2014). Lead overdose in children causes lower IQ, impaired development. The accumulation of heavy metals in the water sources is another source of worry as these metals pose a severe danger when consumed and can lead to kidney and liver infections (WHO, 2017).

Lead overdose can be treated, but the damage done cannot be reversed. In adults, lead overdose causes loss of memory and insomnia. Accumulation of lead via oral ingestion and dermal absorption is a possibility (Flora et al., 2012). In cattle, signs that appear within 24-48 hours of exposure to lead overdose include ataxia, blindness, salivation, spastic twitching of the eyelid, jaw champing, muscle tremors and convulsion. Diseases/Clinical signs associated with coliform bacteria are urinary tract infections, bloody diarrhoea, stomach cramps, vomiting and occasionally fever and pneumonia. If bacteria are found in water, it is not good for drinking, washing of fruits and vegetables, cooking and brushing of teeth (UNICEF, 2017). Bacteria found in drinking water cause enteric disease, and this is a threat to public health. Lead and faecal coliform in domestic water necessitates the constant monitoring of the wells (UNICEF, 2017). The aim of this study is to examine lead and enteric bacteria contamination of water from wells and shallow boreholes in peri-urban areas of Makurdi.

\section{Materials and Methods \\ Study design}

This study was conducted in Makurdi, the capital city of Benue State. It is situated on the flood plains of the lower Benue valley in Northcentral Nigeria on Latitude $7^{\circ} 38^{\prime} \mathrm{N}-7^{\circ} 50^{\prime} \mathrm{N}$ and longitude $8^{\circ} 24^{\prime} \mathrm{E}$ and $8^{\circ} 38^{\prime} \mathrm{E}$. The physiographic characteristics span between 73 - $167 \mathrm{~m}$ above sea level. Due to the generally low relief, sizeable portions of Makurdi are waterlogged and flooded during heavy rainfalls. This is reflected in the general rise in the level of groundwater in wells during the wet season. The drainage is dominated by river Benue which transects the town into Makurdi North and South banks (Aper \& Agbehi, 2011).

\section{Study sites}

Makurdi was stratified into four sections, South, North, East and West represented by Agbough in Modern Market Ward (location A), Yagba in North Bank II Community (location B), Kanshio in Bar ward (location C) and Fidii ( location D), respectively.

\section{Sample collection and storage}

Water samples were randomly collected from the "locations" visited fortnightly for 12 months, beginning from October 2015 to September 2016. For each "location," two wells each of non-cased wells (NCW), burnt brick cased wells (BBW), concrete cased wells (CCW), and shallow boreholes (SBH) were randomly sampled. One litre of water was obtained from each well at every visit to the four sites, and eight water samples were collected for each visit. A total of 768 samples were collected in pre-cleaned 1 $\mathrm{L}$ plastic containers and put in icepacks, which were 
then taken to the laboratory for analysis. The water samples that were not analyzed immediately were stored under refrigeration at $4^{\circ} \mathrm{C}$ until processed. None of the samples was stored beyond the duration of 1 week.

\section{Assessment of lead metal}

The lead content in the water samples was determined using the method described by Afolabi et al. (2012). For each water sample, $100 \mathrm{mls}$ were transferred into a beaker and $5 \mathrm{ml}$ of $\mathrm{HNO}_{3}$ was added. The beaker with the content was placed on a hot plate and evaporated down to about $20 \mathrm{ml}$, and the content were allowed to cool to room temperature; $5 \mathrm{ml}$ Nutric Acid (HNO3) was added. The beaker was covered with a watch glass and returned to the hot plate for more heating. Small portions of Nutric Acid (HNO3) were added until the solution appeared light coloured and clear. The beaker wall and the watch glass were washed down with distilled water. The sample was filtered to remove insoluble material that could clog the atomizer. The volume of the sample was made up to mark (100ml) with distilled water. Distilled water was used as blank and prepared in a similar way. After wet acid digestion, Atomic Absorption Spectrophotometer (AAS) Perkins Elmer 305B USA) was used in the determination of the concentration of lead in the water samples. A calibration curve of lead was prepared using aliquots from the standard stock solution for lead ordered from Chem-lab NV Industrie Zone DE Arend 2 B-82/0 Zedelgem-Belgium. The working standard was prepared in the laboratory by diluting $10 \mathrm{mls}$ of the $1000 \mathrm{ppm}$ standard using deionized water to give a solution of $100 \mathrm{ppm}$ for the working standard. From the working standard, the standard for calibration curve for lead was prepared within the linear range.

\section{Assessment of some enteric bacteria}

Total coliform counts in the sample water were determined using the multiple tube fermentation technique as described by Park (2007).

\section{Presumptive test}

Three sets of five screw-capped tubes in a rack, each containing $10 \mathrm{ml}$ of MacConkey broth (OXIDE) and inverted Durham vials were inoculated with $10 \mathrm{mls}$, $1 \mathrm{ml}$ and $0.1 \mathrm{ml}$ of the water sample, respectively, according to standard methods. These were incubated at $35^{\circ} \mathrm{C}$ for 48 hours and observed for the production of acids resulting in cloudiness (evidence of growth) and the evidence of gas production. Tubes with cloudiness and evidence of gas production were regarded as positive for coliform. After enumeration, the number of positive tube combinations from the sets was used to determine the most probable number (MPN) of coliform $/ 100 \mathrm{ml}$ in the water sample reading from the MPN index statistics table.

\section{Confirmatory test}

Detection of total coliform and faecal coliforms was done by taking $1 \mathrm{ml}$ of broth from the positive tube with the smallest inoculum using sterile Pasteur pipette into $10 \mathrm{ml}$ of $2 \%$ brilliant bacteria green lactose bile (OXIDE) in duplicates. These were incubated at $35^{\circ} \mathrm{C}$ and $44^{\circ} \mathrm{C}$ respectively for $24-48$ hours and observed for cloudiness and gas production. Tubes that were cloudy with gas production at both temperatures were considered confirmed positive for faecal coliforms, while those that showed growth with gas production were nonfaecal coliforms.

\section{Completed test}

Organisms from positively confirmed tubes were isolated in pure culture on broth eosin- methyl blue (EMB) agar plates and incubated at $35^{\circ} \mathrm{C}$ for 48 hours. Coliform bacteria produced brick-red colonies with a surrounding zone of precipitated bile on MacConkey and red colonies with a metallic green sheen of the surrounding medium on EMB picked, and representative colonies were stained by Gram's method to detect Gram-negative, non-sporulating rods microscopically. From each plate, one or more colonies of non-lactose fermenting bacteria typical of members of Enterobacteriaceae was picked for identification.

\section{Biochemical Identification of bacteria}

Commercially produced Enterobacterial identification systems (Microbact Kits Oxoid Ltd England) was used to identify the species of waterborne Enterobacteriaceae of public health importance.

Biochemical characterization and isolation of bacteria species

Oxoid microbact identification kits (OXOID Ltd England) are a standardized micro-substrate system designed to stimulate conventional substrates used to identify Enterobacteriaceae and common miscellaneous gram-negative bacilli (MGNB) was used. Organism's identification is based on PH change and substrate utilization as established by APHA (2002). An 18-24-hour pure culture of the organisms to be identified was obtained. MacConkey agar was used to culture the organisms. An oxidase test was performed on the organisms to be identified. Onethree isolated colonies were picked from an 18-24hour culture and emulsified in $5.0 \mathrm{ml}$ of sterile saline 
solution. This was mixed thoroughly to prepare a homogeneous suspension. The wells of the individual substrate set were exposed by cutting the end tag of the sealing strip and slowly peeling it back. The inoculated rows were resealed with an adhesive seal and the specimen identification number written on the end tag with a marker pen. This was incubated at 35 oc for $18-24$ hours. The $12 \mathrm{~B} / 24 \mathrm{E}$ strip was read at 24 hours to identify Enterobacteriaceae, the strips were removed from the incubator the sealing tape was peeled back, and all positive result was recorded. The reactions were evaluated as positive or negative by comparing them with the colour chart. The results were recorded under the appropriate heading on the report form. The MicrobactTM Computer-aided identification package designed by OXOID was used .

\section{Data analysis}

All data generated during this study was expressed as Mean and standard deviation (mean \pm SD). The analysis of variance (ANOVA) with Turkey's Post hoc test was used to analyze differences in Lead and bacteria counts between the different well types and locations. The level of significance was set at 0.05 for the P-value.

\section{Results}

Concentration of lead in the wells and locations (Table 1) shows a significant difference in lead concentration in the well types and locations $(p<$ 0.05 ). The highest lead concentration $0.135 \mathrm{mg} / \mathrm{L}$ ( $p$ value 000) was recorded in Modern market followed by $0.079 \mathrm{mg} / \mathrm{L}$ also in Modern market. The lead concentration in fidii, Kanshio and North bank were $0.77 \mathrm{mg} / \mathrm{L}, 0.73 \mathrm{mg} / \mathrm{L}$ and $0.030 \mathrm{mg} / \mathrm{L}$, respectively. With regard to the type of well; the highest lead concentration was recorded in Burnt brick cased well $(0.135 \mathrm{mg} / \mathrm{L})$ followed by $0.098 \mathrm{mg} / \mathrm{L}$ still in burnt brick cased well and then Non-cased well $0.079 \mathrm{mg} / \mathrm{L}$. The shallow borehole $(0.017 \mathrm{mg} / \mathrm{L})$ recorded the least lead concentration.

Bacteriological isolates (Table 2) showed that in respect to the wells, the levels of $E$. coli count in Noncased well was $0.401 \pm 0.050$, burnt brick cased well $0.385 \pm 0.118$, concrete cased well $0.120 \pm 0.075$, and Shallow boreholes was $0.000 \pm 0.000$. The levels of Salmonella Subsp 3B count in Non-cased well was $0.250 \pm 0.036$, burnt brick cased $0.125 \pm 0.027$, concrete cased well $0.000 \pm 0.000$ and shallow borehole $0.000 \pm 0.000$. The levels of Enterobacter agglomeran complex count in Non-cased well $4.115 \pm$ 0.168 , burnt brick cased $2.729 \pm 0.160$ concrete cased well $1.505 \pm 0.123$ and shallow borehole $0.630 \pm$ 0.083 . The levels of Klebsiella pneumoniae in Noncased $3.260 \pm 0.168$, burnt brick cased $2.469 \pm 0.112$, concrete cased well $1.495 \pm 0.099$ and shallow borehole $0.823 \pm 0.068$. The levels of Citrobacter freundii count in Non-cased well $1.375 \pm 0.137$, shallow borehole burnt brick cased 0. $589 \pm 0.067$, concrete cased well $0.604 \pm 0.077$ and shallow borehole $0.385 \pm 0.053$, respectively. Irrespective of the location the E. coli, Salmonella subsp $3 B$, Enterobacter agglomeran complex $(p<0.00)$ and Citrobacter freundii $(p<0.00)$ content of all the wells were significantly different as shown in (Table3). The results of the factors affecting the bacteria isolates of water (Table 4) indicates that the well type and location as well as the combination of these factors predicated the bacteria isolates of water in the wells in peri-urban Makurdi. With respect to location. The quantity of $E$. coli in location B (0.6615) was significantly $(p<0.00)$ higher than in location $C$ (0.2500), D (0.0521) and $A(0.0000)$. The level of Salmonella subsp 3B in location C (0.2552) was significantly $(p<0.000)$ higher than in location $B$ (0.1250), locations A and D exhibited similar levels. The level of Enterobacter agglomeran complex in location A (3.5677) was significantly $(p<0.00)$ higher

Table 1. Mean annual lead concentration of water from wells and boreholes in peri-urban areas of Makurdi (October 2015- September 2016)

Location

\begin{tabular}{lllllll} 
Well type & Modern Market & North Bank & Kanshio & Fidii & Mean & WHO max \\
\hline Non-cased & $0.079 \pm 0.009^{\mathrm{b}}$ & $0.030 \pm 0.002^{\mathrm{a}}$ & $0.073 \pm 0.014^{\mathrm{b}}$ & $0.077 \pm 0.031^{\mathrm{b}}$ & $0.065 \pm 0.009$ & 0.01 \\
\hline Shallow bore hole & $0.029 \pm 0.004^{\mathrm{bd}}$ & $0.017 \pm 0.002^{\mathrm{ac}}$ & $0.017 \pm 0.002^{\mathrm{ac}}$ & $0.032 \pm 0.007^{\mathrm{bc}}$ & $0.024 \pm 0.002$ & 0.01 \\
\hline Burnt brick cased & $0.135 \pm 0.06^{\mathrm{bd}}$ & $0.044 \pm 0.002^{\text {ad }}$ & $0.063 \pm 0.004^{\mathrm{ac}}$ & $0.098 \pm 0.016^{\mathrm{bd}}$ & $0.085 \pm 0.005$ & 0.01 \\
\hline Concrete cased & $0.042 \pm 0.008^{\mathrm{bc}}$ & $0.036 \pm 0.006^{\mathrm{bd}}$ & $0.020 \pm 0.002^{\mathrm{ac}}$ & $0.039 \pm 0.10^{\mathrm{bc}}$ & $0.034 \pm 0.003$ & 0.01 \\
\hline
\end{tabular}

Keys: values are means $\pm S D, n=192$ values that have different superscripts on the same row are significant at $P<0.05$ a - significantly decreased along the row

b - Significantly increased along the row

c - significantly decreased along the column

$d-$ significantly increased along the column 
Table 2: Mean bacteriological quantity in sampled water from wells and shallow boreholes in a peri-urban area of Makurdi (October 2015-September 2016)

\begin{tabular}{lllll}
\hline Microbes & \multicolumn{4}{c}{ Well type } \\
\cline { 2 - 5 } & Non-cased & Shallow borehole & Burnt brick cased & Concrete cased \\
\hline Escherichia coli & $0.401 \pm 0.050$ & $0.00 \pm 0.000$ & $0.385 \pm 0.118$ & $0.120 \pm 0.075$ \\
\hline Salmonella subsp 3b & $0.250 \pm 0.036$ & $0.000 \pm 0.000$ & $0.125 \pm 0.027$ & $0.000 \pm 0.000$ \\
\hline Enterobacter agglomeran complex & $4.115 \pm 0.168$ & $0.630 \pm 0.083$ & $2.729 \pm 0.160$ & $1.505 \pm 0.123$ \\
\hline Klebsiella pneumoniae & $3.260 \pm 0.168$ & $0.823 \pm 0.068$ & $2.469 \pm 0.112$ & $1.495 \pm 0.099$ \\
\hline Citrobacter freundii & $1.375 \pm 0.137$ & $0.385 \pm 0.053$ & $0.589 \pm 0.067$ & $0.604 \pm 0.077$ \\
\hline
\end{tabular}

Keys: Values are means \pm SD, $n=192, a=0.05 p$-value

Table 3: Mean bacteriological quantity of sampled water from wells and shallow borehole in a peri-urban area of Makurdi based on location (October 2016-September 2017)

\begin{tabular}{llllll}
\hline Microbes $\left(\mathrm{CFU} \times 10^{5}\right.$ ) & \multicolumn{2}{c}{ Location } & \\
& Modern Market & North Bank & Kanshio & Fidii & P-value \\
\hline Escherichia coli & $0.000 \pm 0.000^{\mathrm{a}}$ & $0.693 \pm 0.188^{\mathrm{d}}$ & $0.25 \pm 0.049^{\mathrm{c}}$ & $0.052 \pm 0.031^{\mathrm{b}}$ & 0.000 \\
Salmonella subsp 3b & $0.000 \pm 0.000^{\mathrm{a}}$ & $0.255 \pm 0.050^{\mathrm{b}}$ & $0.255 \pm 0.047^{\mathrm{b}}$ & $0.000 \pm 0.000^{\mathrm{a}}$ & 0.000 \\
Enterobacter agglomeran complex & $3.568 \pm 0.301^{\mathrm{c}}$ & $2.833 \pm 0.251^{\mathrm{c}}$ & $1.729 \pm 0.176^{\mathrm{b}}$ & $1.380 \pm 0.174^{\mathrm{a}}$ & 0.000 \\
Klebsiella pneumoniae & $3.037 \pm 0.024^{\mathrm{b}}$ & $2.302 \pm 0.180^{\mathrm{b}}$ & $1.526 \pm 0.13^{\mathrm{a}}$ & $1.417 \pm 0.141^{\mathrm{a}}$ & 0.000 \\
Citrobacter freundii & $1.880 \pm 0.205^{\mathrm{c}}$ & $0.451 \pm 0.408^{\mathrm{a}}$ & $0.729 \pm 0.13^{\mathrm{b}}$ & $0.501 \pm 0.412^{\mathrm{a}}$ & 0.002 \\
\hline
\end{tabular}

Keys: Values are means $\pm S E M, n=192$, values that have different alphabet superscripts on the same row are significantly different at $\mathrm{P}<0.05$ level.

Table 4: Factors that Affects the Bacteria Isolate of Water from Wells and Bore-Holes in Peri-Urban Area of Makurdi (October 2015 to September 2016)

\begin{tabular}{|c|c|c|c|c|c|}
\hline Factors & E. coli & $\begin{array}{l}\text { Salmonella subsp } \\
3 b\end{array}$ & $\begin{array}{l}\text { Enterobacter } \\
\text { Agglomeran complex }\end{array}$ & $\begin{array}{l}\text { Klebsiella } \\
\text { Pneumoniae }\end{array}$ & Citrobacter freundii \\
\hline \multicolumn{6}{|l|}{ Location } \\
\hline Modern Market & $0.000^{\mathrm{a}}$ & $0.000^{\mathrm{a}}$ & $3.567^{d}$ & $3.036^{c}$ & $0.151^{a}$ \\
\hline North Bank & $0.661^{c}$ & $0.125^{b}$ & $2.302^{c}$ & $2.067^{b}$ & $0.192^{\mathrm{a}}$ \\
\hline Kanshio & $0.250^{\mathrm{ab}}$ & $0.255^{c}$ & $1.729^{b}$ & $1.526^{\mathrm{a}}$ & $0.729^{b}$ \\
\hline Fidii & $0.052^{b}$ & $0.000^{\mathrm{a}}$ & $1.380^{\mathrm{a}}$ & $1.416^{\mathrm{a}}$ & $0.233^{a}$ \\
\hline \multicolumn{6}{|l|}{ Type of Well } \\
\hline Shallow borehole & $0.057^{a}$ & $0.000^{a}$ & $0.630^{a}$ & $0.822^{a}$ & $0.385^{a}$ \\
\hline $\begin{array}{l}\text { Concrete cased } \\
\text { well }\end{array}$ & $0.119^{a}$ & $0.005^{a}$ & $1.505^{b}$ & $1.494^{\mathrm{b}}$ & $0.604^{b}$ \\
\hline Burnt brick cased & $0.385^{b}$ & $0.125^{b}$ & $2.729^{c}$ & $2.468^{c}$ & $0.588^{b}$ \\
\hline Non- cased well & $0.401^{b}$ & $0.250^{c}$ & $4.114^{d}$ & $3.260^{d}$ & $1.375^{c}$ \\
\hline
\end{tabular}

Values are mean \pm SD $n=192$, values that have different alphabet superscripts on the same row are significantly different at 0.05 level of significance.

than in location B (2.3021), C (1.7292) and D (1.3802). The levels of Klebsiella pneumoniae in location $A$ (3.0365) was higher than in location B (2.0677), C (1.5261) and D (1.4167). Concerning the wells, the levels of $E$. coli in non-cased well (0.4010) was significantly $(p<0.00)$ higher than in burnt brick cased (0.3854), concrete cased well (0.1198) and shallow bore-hole (0.0573). The levels of Salmonella subsp 3B in Non-cased well $(0.2500)$ was significantly $(p<0.00)$ higher than in Burnt brick cased well (0.125). Concrete cased well (0.005) and shallow bore-hole
(0.000). The levels of Enterobacter agglomeran complex in Non-cased well (4.115) was significantly $(p<0.00)$ higher than burnt brick cased (2.729), concrete cased well (1.505) and shallow bore-hole (0.630). The levels of Klebsiella Pneumonia in noncased well $(3.260)$ is significantly $(p<0.00)$ higher than burnt brick cased (2.468), concrete cased well (1.495) and shallow borehole (0.823). The levels for Citrobacter freundii in non-cased well (1.375) is significantly $(p<0.00)$ higher than concrete cased well (0.604), burnt brick cased well (0.588) and shallow 
bore-hole (0.385). Irrespective of the location, the $E$. coli, Salmonella subsp 3B, Enterobacter agglomeran complex, Klebsiella Pneumonia and Citrobacter freundii contents in all the wells were significantly $(p<0.00)$ different.

\section{Discussion}

The populace is often ignorant of possible chemical and microbial contaminants in untreated water and is often deceived by the sparkling nature of water. All wells recorded significant mean levels of lead above $0.01 \mathrm{mg} / \mathrm{L}$ WHO permissible limit in water. Significant lead recorded may be due to increased use of chemical fertilizers like Phosphate and micronutrient fertilizers, on farms that find their way into groundwater environment, commercial activities like washing of parts of the vehicle with imported fuel, charging of car battery, tyres used for burning the skin of animals after slaughter may leach into the wells. Yusuf et al. (2017) also found water samples from wells and bore-holes around Kashere and its environs, upper Benue trough to contain lead concentration above World Health Organization Standards. Ejembi et al. (2018) also reported the presence of lead from shore sediments from the bank of river Benue. Increased use of lead as part of fertilizers and pesticides for agricultural purposes has resulted in the pollution of soil which has had a serious environmental impact (Talali \& Khanlari, 2008; Parizanganeh et al., 2010). These agricultural activities have resulted in the contamination of groundwater resources (Ebrahimi et al., 2011). Exposure can result in intellectual disability, birth defects, kidney damages and even death Papanikolaou et al. (2005). Even though humans are exposed through multiple sources, inhalation through air-borne dusts containing lead particles and ingestion through food or water contaminated by lead are considered the most probable routes of exposure (Karrari et al., 2012). The presence of lead metal in all the wells and boreholes can be attributed to deep percolation from surface sources due to increased agricultural activities and their natural occurrence in the underlying geological formation (Ocheri et al., 2014). Since the people of Makurdi peri-urban area depend on these waters for all their daily domestic needs, long term accumulation of lead in the body via oral ingestion and dermal absorption is a possibility (Mark et al., 2009). Since the hand-dug wells and shallow bore-holes sampled were not located near any source of industrial battery wastes and yet had significant levels of lead contaminants, data obtained confirmed earlier research findings that several other less recognized sources apart from occupational or industrial release of lead wastes could contribute significantly to the problem of pollution of groundwater by lead (Erah et al., 2002). The result obtained in this study corroborates the findings of Ocheri et al. (2014) that confirmed significant concentration of metal lead in the underground water sources of Makurdi Metropolis. The results obtained for bacteria isolates is of public health importance since the presence of any type of coliform bacteria in drinking water is not acceptable by World Health Organization water quality standards (WHO, 2017). This result supports earlier reports by Mile et al. (2012) for wells in North Bank, one of the locations covered by this study. The indiscriminate sinking of boreholes near toilet soak-away, pit latrines, dirty gutters and poor drainages had been known to contribute to the presence of contaminants in water from bore-holes. Indiscriminate open defecation by humans is common practice in these locations, and this could be a source of faecal coliform contamination of the wells from surface run-offs. The contamination of all wells could be due to improper construction of wells, refuse dumping sites and various human activities around the wells. The multipurpose use of the bailing buckets could easily introduce bacteria into the water (Tse \& Adamu, 2012). The bacterial species isolated in this study are consistent with the result of Mile et al. (2012). who reported the presence of the same bacterial species in burnt brick cased wells and bore-holes at Wadata along River Benue in Makurdi Metropolis, while Aguoru et al. (2015) characterized all these bacteria isolate on edible fruits in Makurdi Metropolis.The bacterial pollution of well water sources is mostly due to watershed erosion and drainage from sewage and swamps (Ajotaibi, 2009). Due to space limitations, crowding and lack of proper drainage network, the septic pit system is extensively used in Makurdi periurban area, and seepage from these underground pits into the nearby wells might have contaminated the well water sources. All the bacteria isolated in this study were also reported by Adeiza et al. (2017) for some boreholes in Kano Metropolis. The presence of $E$. coli in the water sample might have resulted from surface overflow of reptile droppings where it has been isolated before (Walterson \& Stavrinides, 2015) into the water source. $E$ coli is found in the intestinal tract of warm-blooded animals, and it cannot live long outside the host. The detection of $E$ coli is indicative of recent faecal contamination or recent contact with humans or animals, and it also shows the possible presence of other pathogenic organisms, intestinal illness-causing bacteria are likely present in the water. 
The presence of coliform bacteria in the sampled water in this study is of serious public health concern because these bacterial species are associated with diarrhoea, urinary and respiratory tract infections and can be pathogenic (Nwekaven et al., 2017).

In conclusion, the presence of lead in the wells and shallow boreholes may be due to the increased use of chemical fertilizers on farms that find their way into the groundwater environment. For the bacteria isolates in water sampled from hand-dug wells and shallow boreholes, it indicates problems with the well construction or with the filtering soil or bedrock near where the water is drawn. It may also likely be a problem with the casing if it leaks, not the right height, or there is not enough backfill surrounding it. The people living in the peri-urban area of Makurdi consuming this water are potentially exposed to possible acute, subchronic or even chronic plumbism and water-borne diseases like -typhoid fever, cholera and dysentery.

Therefore, the populace should be educated on the importance of maintaining a clean and hygienic environment around the wells and shallow boreholes to ensure the safety of water from the wells and shallow boreholes. It is therefore recommended that appropriate measures should be taken to treat the water by way of disinfection, boiling and filtration to safeguard drinking water quality. All land activities capable of polluting water sources, both surface and underground, should be properly regulated to safeguard their quality.

\section{Acknowledgement}

We gratefully thank Dr Oscar Kolndadacha of the College of Veterinary Medicine, the Federal University of Agriculture Makurdi, for helping us in the laboratory. We also thank the owners of wells and boreholes for granting us access to their location.

\section{Conflict of Interest}

The authors declare that there is no conflict of interest.

\section{References}

Adeiza ZO, Zakari HH \& Jere SA (2017). Assessment of bacterial quality of some selected boreholes water in Kurnar Asabe Quarters, Kano Metropolis. Annals of Microbiology and Infectious Diseases, 1(2): 11-17.

Adekunle AS (2008). Impact of Industrial effluent on quality of well water within Asa Dam Industrial Estate, Ilorin, Nigeria. Nature and Science, 6(3): 1-5
Afolabi TA, Ogbuneke CC, Ogunkunle OA \& Bamiro FO (2012). Comparative assessment of the potable quality of water from industrial and rural parts of Lagos, Nigeria, Ife Journal of Science, 14(2): 1 - 20.

Aguoru CU, Maaji S \& Olasan JO (2015). Bacteria contaminants on surface of some edible fruits sold in Makurdi Metropolis, Benue state, Nigeria. International Journal of Current Microbiology and Applied Science, 4(6): 334- 340

Ajotaibi EIS (2009). Bacteriological assessment of Urban Water Sources in Khamis Mushait Governorate, Southwestern Saudi Arabia. International Journal of Health Geography, 16(18): $38-55$.

Aper JA, \& Agbehi SI (2011). The Determining factors of rural water supply pattern in Ugbokolo Community, Benue State- Nigeria. Journal of Sustainable Development, 4(2): 225 -233

APHA (2002). Report of the 2002 APHA House of Delegates. doi.10.1331/108658002764653825.

Ebrahimi A, Amin MM, Hashemi H, Foladifard R \& Vahiddasterd M (2011). A survey of ground water chemical quality in Sajad Zarinshahr. Health Systems Research, 6(Supplement): 918-926.

Ejembi E, Sombo T \& Ugwanyi J (2018). Assessment of heavy metals concentration in shore sediments from the Bank of River Benue, North-Central Nigeria. Journal of Geoscience and Environment Protection, 6: 25-48 doi.10.4235/gep.2018.64003.

Erah PO, Akujieze CN \& Oteze AE (2002). The quality of groundwater in Benin- city. A baseline study on inorganic chemicals and microbial contaminants of health importance in boreholes and open wells. Tropical Journal of Pharmaceutical Research, 1(2): 75-82

Flora G, Gupta D \& Tiwari A (2012). Toxicity of Lead: A review with recent updates. Interdisciplinary Toxicology, 5(2): $47-58$.

Gerba CP, Rose JB \& Haas CN (1996). Sensitive populations: Who is at greater risk? International Journal of Food Microbiology, doi.10.1016/0168-1605(96)00996-8.

Jaishankar M, Tseten T, Naresh A, Mathew BB \& Krishnamurthy NB (2014). Toxicity, mechanism and health effects of some heavy metals. Interdisciplinary Toxicology, 7(2): $60-72$.

Karrari P, Mehrpour O, \& Abdollahi M (2012). A systemic review on status of lead pollution 
and toxicity in Iran; Guidance for preventive measures. DARU Journal of Pharmaceutical Sciences, 20(2): $12-16$.

Mark FT, Jenny DSC, Stauber L, Les PHD, Dale S, Hale BSC, Henderson B, Izard E \& Kerynne B (2009). The absorption of ionic lead compounds through the skin of mice. Journal of Nutritional and Environmental Medicine, 8(1) 19-23: doi. Org/10.1080/13590849862267

Mile II, Amonum JI \& Sambe NN (2012). Heavy metal in ground water in urban and sub-urban Makurdi, Nigeria. Pakistan Journal of Chemistry, 1 (3): 87-90

Mintz E, Bartram J, Lochery P \& Wegelin M (2001). Not just a drop in the bucket: Expanding access to point of use water treatment systems. American Journal of Public Health, 91, 1565-1570.

Nwekaven SS, Aorkwagh MT, Gundu EG \& Yange T (2017). Physico-chemical and microbiological analysis of well water samples in settlements around Akperan Orshi College of Agriculture, Yandev. International Journal of Sciences and Technology, 6(1): 642-649.

Ocheri M, Ahola O \& Bernard A (2012). Profile of water related diseases in Benue State, Nigeria. American Journal of Human Ecology, doi.10, 11634/216796221504192.

Ocheri MI, Odoma LA \& Umar ND (2014). Around water quality in Nigerian urban areas. A review. Global journal of science frontier research 14(3): $1-10$.

Papanikolaou NC, Hatzidaki EG, Bolivians S, Tzanakakis GN \& Tsatsakis AM (2005). Lead toxicity update. A brief review. Medical Science Monitor, 10(11): RA329-RA336.

Parizanganeh A, Haji Sultans P \& Zaamni (2010). Assessment of heavy metal pollution in surficial soils surrounding Zinc Industrial
Complex in Zanja- Iran. Procedia Environmental Science, doi.10.161j. Proenv.

Park K (2007). Preventive and Social Medicine Nineteenth edition. N/S Banarisdasbhanot Publishers, Prem Nager, Jabalpur, 482001, India. Pp 213 - 222.

Talali M \& Khanlari ZV (2008). Environmental contamination of $\mathrm{Zn}, \mathrm{Cd}, \mathrm{Ni}, \mathrm{Cu}$ and $\mathrm{Pb}$ from Industrial areas in Hamadan provinces, Western Iran. Environmental Geology, 55:1537-1543 doi: 10.1007/S 002541103-1.

Tse AC \& Adamu Cl (2012) Assessment of anthropogenic influence on quality of groundwater in hand-dug wells in parts of Makurdi metropolis, North Central Nigeria. Ife Journal of Science, 14(1): 28 - 33.

UNICEF (2017). Fact Sheets on UNICEF Nigeria's Education, Health. HIV/AIDS. Nutrition Child protection and Wash programmes UNICEF Nigeria. Abuja.

UNICEF (2018) Multiple Indicator Cluster Survey 2016 - 17, survey findings Report Abuja Nigeria: National Bureau of Statistics and United Nations Children's Fund.

Walterson AM \& Stavrinides J (2015). Pantoea: Insights into a highly versatile and diverse genus within the Enterobacteriaceae. FEMS Microbiology Reviews, 39(6): 968-984.

WHO (2017). Guidelines for Drinking Water Quality Fourth edition, incorporating the first addendum. ISBN 978-92-4-154995-0

Won G (2012). Microbial quality of private well drinking water in north eastern Ohio. Journal of Environmental Quality, 3(5): 213-222.

Yusuf A, Olasehinde A, Mboringong MN, Tabale RP \& Daniel EP (2017). Evaluation of heavy metals concentration in groundwater around Kashere and Its environs, Upper Benue Trough, North-eastern Nigeria. Global Journal of Geological Sciences, doi.10.4314/gigs.v16:1-4. 